DOE/EK

DOE/ER/61252--TI

DE93 006091

CARBON DIOXIDE RESEARCH PROGRAM

Dr. Park S. Nobel
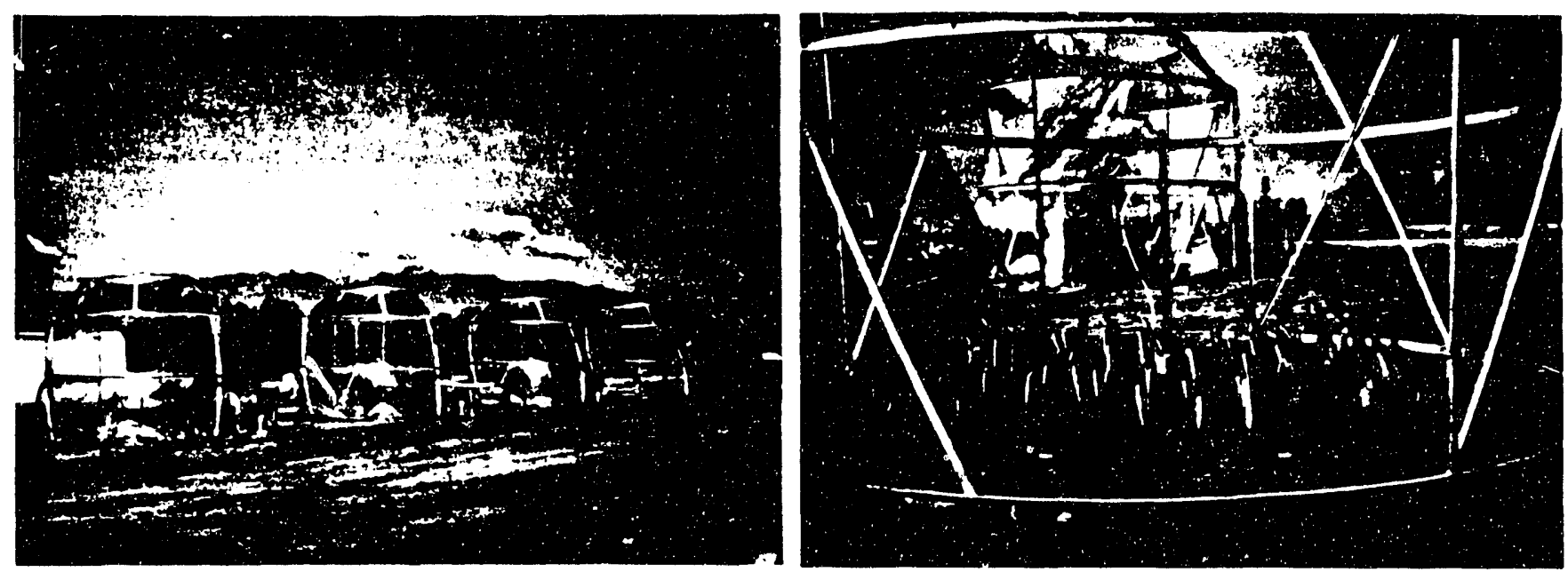

Open-top chambers at University of California at Riverside

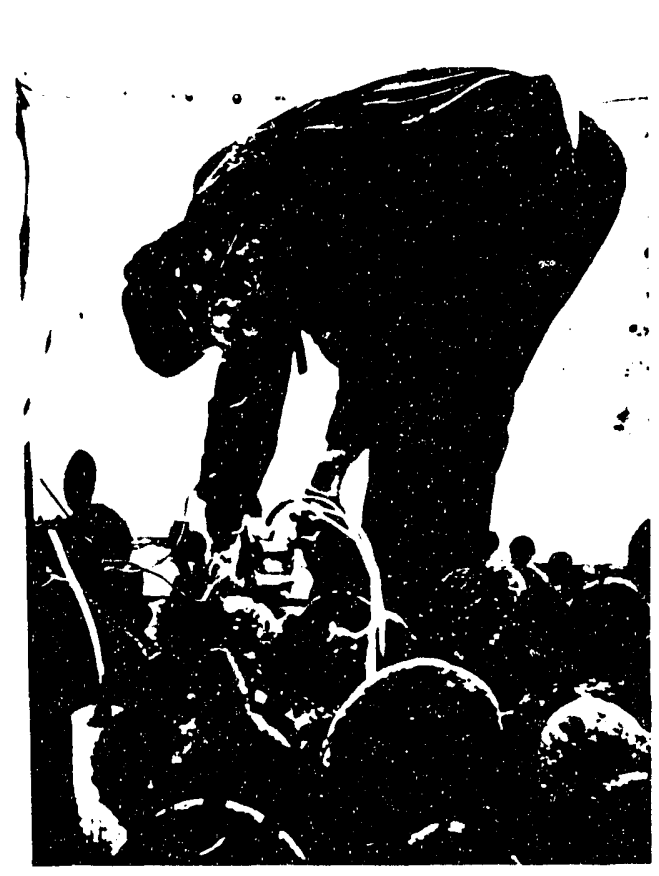

(A)

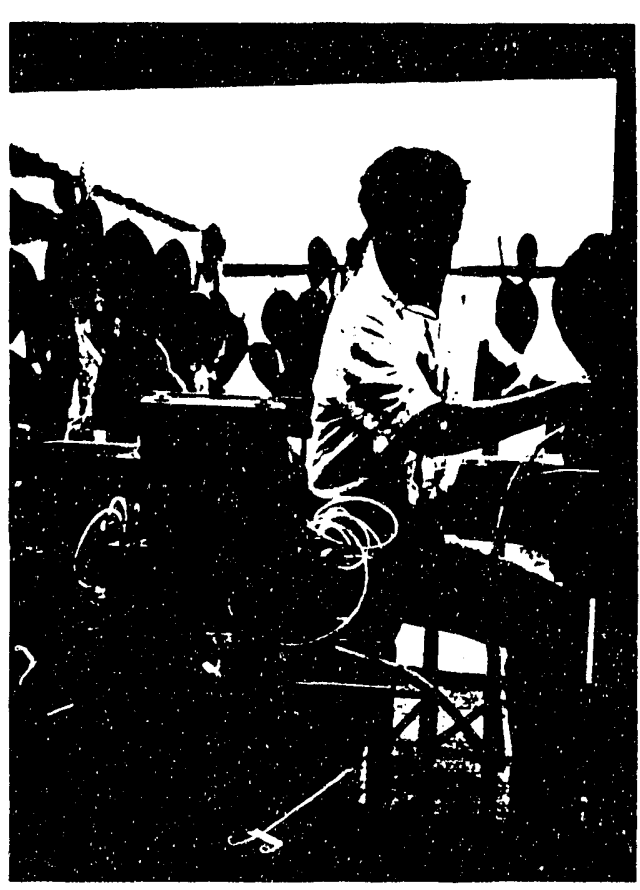

(B)

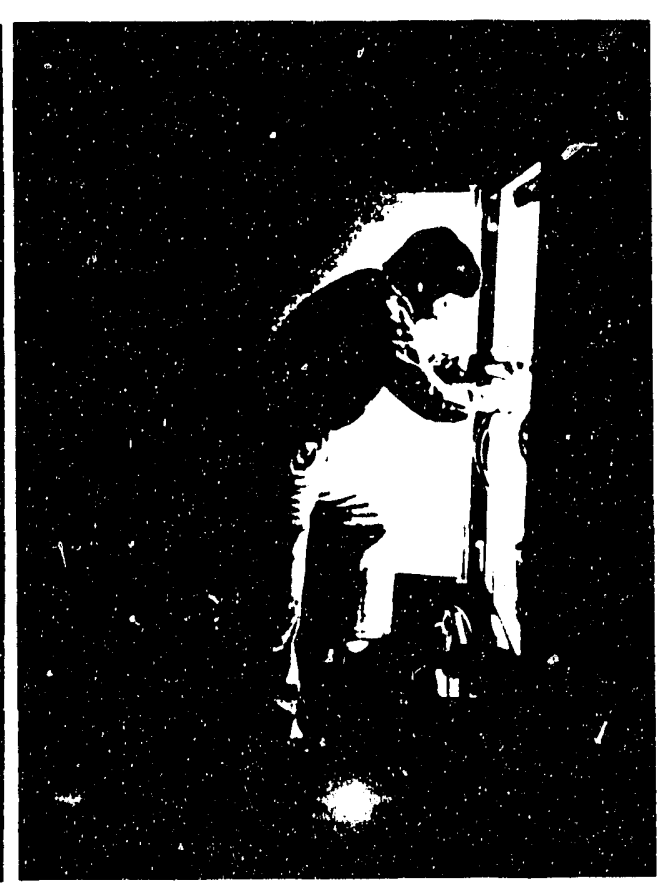

(C)

Gas exchange measurements in open-top chambers at UCR (A), in walk-in growth rooms at UCLA (B), and in Conviron growth chambers at UCLAA (C) 


\begin{abstract}
$\mathrm{CO}_{2}$ Exchange, Environmental Productivity Indices, and Productivity of opuntia ficus-indica under current and Elevated $\mathrm{CO}_{2}$ Concentrations
\end{abstract}

Principal Investigator - Dr. Park S. Nobel

Page

Project 1 PHYSIOLOGY - Dr. Muyi Cui 2

Project 2 PARTITIONING - Dr. Yiqi Luo 5

$\begin{array}{ll}\text { Project } 3 \text { ROOTS - Dr. Patsy Miller } & 10\end{array}$

Project 4 MORPHOLOGY - Dr. Yiqi Lou 15

Droject 5 ABSORPTANCE - Dr. MuYi Cui 18

Project 6 NUTRIENTS AND SECONDARY

COMPOUNDS - Dr. Patsy Miller 21

Project 7 PRODUCTIVITY - Dr. Park Nobel 23

\title{
DISCLAIMER
}

This report was prepared as an account of work sponsored by an agency of the United States Government. Neither the United States Government nor any agency thereof, nor any of their employees, makes any warranty, express or implied, or assumes any legal liability or responsibility for the accuracy, completeness, or usefulness of any information, apparatus, product, or process disclosed, or represents that its use would not infringe privately owned rights. Reference herein to any specific commercial product, process, or service by trade name, trademark, manufacturer, or otherwise does not necessarily constitute or imply its endorsement, recommendation, or favoring by the United States Government or any agency thereof. The views and opinions of authors expressed herein do not necessarily state or reflect those of the United States Government or any agency thereof. 
Project 1 PHYSIOLOGY - Gas Exchange of opuntia ficus-indica Exposed to Elevated $\mathrm{CO}_{2}$

objective: Determine the short and long term responses of photosynthesis and stomatal conductance to elevated $\mathrm{CO}_{2}$ for mother cladodes and newly formed daughter cladodes. specifically, $\mathrm{CO}_{2}$ and $\mathrm{H}_{2} \mathrm{O}$ flux rates, $\mathrm{g}^{s}$, and diel patterns for developing daughter cladodes of the same size (or age) will be monitored.

Location: The research will be conducted in three open-top chambers, $\mathrm{L}$ (ambient $\left.\mathrm{CO}_{2}\right), \mathrm{M}\left(+150 \mathrm{ppm} \mathrm{CO}_{2}\right)$, and $\mathrm{H}(+350 \mathrm{ppm}$ $\left.\mathrm{CO}_{2}\right)$, located at the University of California Riverside research garden.

Plant material: Five replicates of two cohorts will be used from 12 planted cladodes in each chambers. Plants assigned for the measurements are $\mathrm{B} 5, \mathrm{~B} 6, \mathrm{~B} 7, \mathrm{C} 5, \mathrm{C6}, \mathrm{C7}, \mathrm{J} 5, \mathrm{~J} 6, \mathrm{~J} 7, \mathrm{K5}$, $\mathrm{K} 6$, and $\mathrm{K} 7$ (Figure 1).

Measurements: Gas exchange will be measured using a Licor 6200 portable system. Total number of measurements per hour: 1 cohorts $\times 5$ replicates $\times 3$ chambers $=15$. Total number of days required to finish one round of measurement for 2 cohorts $=2$ days.

Schedule: First phase - measurements on plarted cladodes. Gas Ërchange meüsurements will be conducted on liie same planted cladodes (total of 5 replicates) for 24 hours beginning the day after the cladodes are planted in wet soil 
(day 0) and will be measured $0,14,30,45,60,90$, and 120 days after planting.

second phase - measurements on daughter cladodes. $J_{\mathrm{cO2}}$ and $J_{\mathrm{H} 20}$ will be measured continuously for 24 hours $0,3,7,14,30$, 45, 60, 90, and 120 days after newly initiated spring 1992 daughter cladodes reach a measurable size. Five replicate daughter cladodes will be measured in the $L, M$, and $H$ chambers.

Third phase - measurements on two cohorts. Gas exchange measurements will start when spring 1993 daughter cladodes are appearing on the spring 1992 cladodes (in spring, 1993). The measurements will be conducted as close to $0,3,7,14$, $30,60,90,120$ days after the initiation of daughter cladodes as possible. Five replicate sets of Spring 1992 cladodes and their spring 1993 daughter cladodes will be measured in the $L, M$, and $H$, chambers.

Fourth phase - follow-up study. If, after the first year of study, great differences are observed for plants exposed to different levels of $\mathrm{CO}_{2}$, gas exchange will also be conducted during the second year on plants subjected to other environmental stresses, such as shading, water stress and high temperature.

Results expected: 1) Diel $J_{C O 2}$ and total carbon fixation vs days after exposure to elevated $\mathrm{CO}_{2}$ for mothei vladodes 2) WUE and $g^{s}$ vs days after exposure for mother cladodes 
3) diel $J_{\mathrm{CO} 2}$ and total carbon fixation vs age of newly appeared daughter cladodes

4) WUE and $g^{s}$ vs days after exposure for newly appeared daughter cladodes 
Project 2 PARTITIONING - Effects of elevated $\mathrm{CO}_{2}$ on carbon partitioning of opuntia ficus-indica

objectives: 1) study how $\mathrm{CO}_{2}$ concentration affects root/shoot ratio and carbon partitioning of the CAM plants; 2) investigate relevant physiology such as net $\mathrm{CO}_{2}$ exchange and nonstructural carbohydrate.

Growth room experiment

Location: Two existing walk in growth rooms at the Laboratory of Biomedical and Environmental Sciences, UCLA (23-172 A and 23-172 B), will be used. One room will be maintained at ambient levels of carbon dioxide and one at 350 ppm above ambient concentrations. The floor space in each room is $3.25 \mathrm{~m} \times 2.85 \mathrm{~m}=9.26 \mathrm{~m}^{2}$.

Plant material: A total of 88 similar sized cladodes from 1 ascension of 0 . ficus-indica from Mexico (either 1282, 1296, or 1300, which are the ascensions that will be planted in the center $\mathrm{m}^{2}$ of the open top chambers) will be collected from the UCR plantation. Eight cladodes $(4$ replicates $\times 2$ sampling times) will be planted in small pots with a area of - $160 \mathrm{~cm}^{2}, 28$ cladodes in medium pots with an area of -440 $\mathrm{cm}^{2}$ ( 4 replicated $\times 7$ sampling times), and 8 cladodes in large pots with an area of $-1610 \mathrm{~cm}^{2}$ (4 replicates $\times 2$ sampling times; for a total of 44 gladodes in each walk in growth room, one room with ambient $\mathrm{CO}_{2}$ and one with $\mathrm{CO}_{2}$ at +350 ppm above ambient. 
Space requirement per room: If the pot sizes are as described above, $3.5 \mathrm{~m}^{2}$ is needed in each growth room. The three sizes of pots will not be arranged randomly, but will arranged to maximize the space available in the growth room. Pre-planting Measurements: Before planting the length, width, thickness at 4 locations around edge of cladode, and fresh wiight will be measured and the surface area traced to establish the initial condition of the mother cladode.

Growth medium: Plants will be planted in a mixture of 508 soil from the University of California at Riverside research garden and $50 \%$ sandbox sand and will be watered every other day with $1 / 10$ strength Moagland's solution.

Measurements: 1) Dry mass of roots and chlorenychma and water storage paraenchyma tissues of shoots in the medium size pots will be measured at day $7,14,30$ or $45,60,75$, and 90 .

2) Plants in the small and large size pots will be harvested at day $30 / 45$ and 90 .

3) Net gas exchange (NCE) and total non-structural carbohydrates (TNC) will be measured on day $30 / 45$ and 90 on cladodes growing in all three sized pots under elevated and ambient levels of $\mathrm{CO}_{2}$ ( 4 replicates $\times 3$ pot sizes $\times 2 \mathrm{CO}_{2}$ levels $\times 2$ sampling dates $=48$ samples $)$.

Expect=d results: 1) Time course of root/shoot ratio in the medium size pots in two $\mathrm{CO}_{2}$ environments, 2) root/shoot 
ratio, NEC, and TNC for three pot sizes at two rarvest times under two $\mathrm{CO}_{2}$ conditions.

Follow-up experiment: Root/shoot ratios and carbon partitioning will be measured with two carbon dioxide levels, two light levels and three drought periods in the UCLA walk in growth rooms.

\section{Field experiment}

Location: This study will be conducted in the $\mathrm{L}$ (ambient $\mathrm{CO}_{2}$ ), $\mathrm{M}$ $\left(+150 \mathrm{ppm} \mathrm{CO}_{2}\right)$, and $\mathrm{H}\left(+350 \mathrm{ppm} \mathrm{CO}_{2}\right)$ open top chambers at the University of California Riverside research gardens.

Plant material: Cladodes were selected from the edge columns and rows in each chamber, columns $A$ and $I$ and rows 1 and 8 (Table 1). Four cladodes from the $L, M$, and $H$ open top chambers will be labeled at each sampling period. Cladodes $\mathrm{A} 2, \mathrm{Bl}, \mathrm{K} 1$, and $\mathrm{L} 2$ will be sampled in each chamber 14 days after the cladodes are planted in wet soil; cladodes A3, A4, L3 and L4 sampled on day 30; cladodes GI, HI, II, and J1 sampled on day 60 ; and cladodes $C 1, D 1, E 1$, and F1 sampled on day 90 (Table 1).

Schedule: Labeling with ${ }^{14} \mathrm{CO}_{2}$ will be done at midnight on day $12,28,58$, and 88 , after planting.

Measurements: 1) Samples of cladode tissue will be collected with a cork borer 6 times one day after labeling and 3 times two days after labeling. 
2) Carbon dioxide exchange (4 replicates $\times 1$ rohort $\times 3$ chambers $=12$ samples per $\mathrm{hr}$ ) and TNC may be measured on day $30 / 45$ and 90 .

Root/shoot ratio: After all other measurements are completed, above and below-ground tissue of each cladode will be dried and weighted to calculate root/shoot ratios. After a cladode is removed from a open topped chamber to determine root biomass and root/shoot ratios, a replacement cladode from the plantation at UCR will be planted in its place. Expected results: Time course of rook/shoot ratio under three $\mathrm{CO}_{2}$ conditions. Carbon partitioning patterns at four times and NCE and TNC at two tirnes under three $\mathrm{CO}_{2}$ concentrations. 
Table 1. Location of cladodes to be sampled for ${ }^{14} \mathrm{C}$ and root biomass $7,14,21,30,45,60,75$, and 90 days after planting in the I (ambient carbon dioxide), M (+150 ppm carbon dioxide), and H (+350 ppm carbon dioxide) open top chambers at the University of California Riverside research garden.

\begin{tabular}{|c|c|c|c|c|c|}
\hline Day & Chamber & & & adode & Measurements \\
\hline 7 & $\begin{array}{l}\mathrm{L} \\
\mathrm{M} \\
\mathrm{H}\end{array}$ & $\begin{array}{l}\text { A5, } \\
\text { A5, } \\
\text { A5, }\end{array}$ & $\begin{array}{l}\text { A6, } \\
\text { A6, } \\
\text { A6, }\end{array}$ & $\begin{array}{l}\text { L5, L6 } \\
\text { L5, L6 } \\
\text { L5, L6 }\end{array}$ & $\begin{array}{l}\text { R/S ratio } \\
\text { Root morphology }\end{array}$ \\
\hline 14 & $\begin{array}{l}\mathrm{L} \\
\mathrm{M} \\
\mathrm{H}\end{array}$ & $\begin{array}{l}\text { A3, } \\
\text { A3, } \\
\text { A3, }\end{array}$ & $\begin{array}{l}\text { A4, } \\
\text { A4， } \\
\text { A4, }\end{array}$ & $\begin{array}{l}\text { L3, L4 } \\
\text { L3， L4 } \\
\text { L3, L4 }\end{array}$ & $\begin{array}{l}{ }^{14} \mathrm{C} \text { translocation } \\
\mathrm{R} / \mathrm{S} \text { ratio, Root morphology }\end{array}$ \\
\hline 21 & $\begin{array}{l}\text { L } \\
M \\
\mathrm{H}\end{array}$ & $\begin{array}{l}\text { A7, } \\
\text { A7, } \\
\text { A7, }\end{array}$ & $\begin{array}{l}\text { B8, } \\
\text { B8, } \\
\text { B8, }\end{array}$ & $\begin{array}{ll}\text { L7, } & K 8 \\
\text { L7, } & \mathrm{K} 8 \\
\mathrm{~L} 7, & \mathrm{~K} 8\end{array}$ & $\begin{array}{l}\text { R/s ratio } \\
\text { Root morphology }\end{array}$ \\
\hline 30 & $\begin{array}{l}\mathrm{L} \\
\mathrm{M} \\
\mathrm{H}\end{array}$ & $\begin{array}{l}\text { A2, } \\
\text { A2, } \\
\text { A2, }\end{array}$ & $\begin{array}{l}\text { B1, } \\
\text { B1, } \\
\text { B1, }\end{array}$ & $\begin{array}{ll}\mathrm{K} 1, & \mathrm{~L} 2 \\
\mathrm{~K} 1, & \mathrm{~L} 2 \\
\mathrm{~K} 1, & \mathrm{~L} 2\end{array}$ & $\begin{array}{l}{ }^{14} \mathrm{C} \text { translocation } \\
\mathrm{NCE} \text {, TNC } \\
\mathrm{R} / \mathrm{S} \text { ratio, Root morphology }\end{array}$ \\
\hline 45 & $\begin{array}{l}\mathrm{L} \\
\mathrm{M} \\
\mathrm{H}\end{array}$ & $\begin{array}{l}\text { C8, } \\
\text { C8, } \\
\text { C8, }\end{array}$ & $\begin{array}{l}\text { U8, } \\
\text { D8, } \\
\text { D8, }\end{array}$ & $\begin{array}{ll}E 8, & F 8 \\
E 8, & F 8 \\
E 8, & F 8\end{array}$ & $\begin{array}{l}\text { R/S ratio } \\
\text { Root morphology }\end{array}$ \\
\hline 60 & $\begin{array}{l}\mathrm{L} \\
\mathrm{M} \\
\mathrm{H}\end{array}$ & $\begin{array}{l}\text { GI, } \\
\text { GI, } \\
\text { GI, }\end{array}$ & $\begin{array}{l}\mathrm{H} 1, \\
\mathrm{HI}, \\
\mathrm{HI},\end{array}$ & $\begin{array}{l}I 1, J I \\
I 1, J 1 \\
I 1, J I\end{array}$ & $\begin{array}{l}{ }^{14} \mathrm{C} \text { translocation } \\
\mathrm{R} / \mathrm{S} \text { ratio } \\
\text { Root morphology }\end{array}$ \\
\hline 75 & $\begin{array}{l}\mathrm{L} \\
\mathrm{M} \\
\mathrm{H}\end{array}$ & $\begin{array}{l}\text { G8, } \\
\text { G8, } \\
\text { G8, }\end{array}$ & $\begin{array}{l}\text { H8, } \\
\text { H8, } \\
\text { H8, }\end{array}$ & $\begin{array}{l}\text { I8, J8 } \\
\text { I8, J8 } \\
\text { I8, J8 }\end{array}$ & $\begin{array}{l}\text { R/s ratio } \\
\text { Root morphology }\end{array}$ \\
\hline 90 & $\begin{array}{l}\mathrm{L} \\
\mathrm{M} \\
\mathrm{H}\end{array}$ & $\begin{array}{l}\text { C1, } \\
\text { C1, } \\
\text { C1, }\end{array}$ & $\begin{array}{l}\text { D1, } \\
\text { D1, } \\
\text { D1, }\end{array}$ & $\begin{array}{ll}E 1, & F 1 \\
E 1, & F 1 \\
E 1, & F 1\end{array}$ & $\begin{array}{l}{ }^{14} \mathrm{C} \text { translocation } \\
\mathrm{NCE} \text {, TNC } \\
\mathrm{R} / \mathrm{S} \text { ratio, Root morphology }\end{array}$ \\
\hline
\end{tabular}


Project 3 RooTs - Root initiation and development with elevated $\mathrm{CO}_{2}$, shading, and root pruning

Objectives: 1) Understand effects of elevated carbon dioxide on establishment of 0 . ficus-indica by quantifying root initiation on newly planted cladodes, determining costs of root construction, and documenting changes in morphology an anatomy; and 2) to measure the effects of reducing photosynthetic photon flux density (PPFD) and root pruning on root production of 0 . ficus-indica growing with three levels of carbon dioxide.

Growth Room Experiment

Project 3 will utilize the same location, plant material, and pots described for Project 2 - PARTITIONING

Sampling: This project will focus on cladodes growing in the medium sized pots. Four randomly chosen cladodes will be harvested $7,14,30,45,60,75$, and 90 days after planting. Remaining plants will be consolidated after each harvest to reallocate space in the growth room for additional experiments.

Measurements: 1) At each harvest the number of roots originating from the base and from the areoles will be counted to determine if elevated carbon dioxide affects location of root initiativii.

2) The branching pattern of the root mass in each pot will be described. 
3) Roots will be divided into 3 classes, i.e., main roots, second order, and third order roots. As the root mass increases, only random sub-samples of the root mass will be separated into size classes.

4) While the root mass is of a manageable size, the length and area of all roots will be measured. As roots become more abundant, sub-sampling will be used by masuring randomly chosen sections that add up to $10 \mathrm{~cm}$ of root length; 5 replicated $10 \mathrm{~cm}$ lengths of each class of roots will be measured.

5) sub-samples and the total root mass will be dried and weighed.

6) At day $30 / 45$ and 90 , nitrogen concentration, ash, and caloric content will be measured on four replicates of the three root size classes from cladodes growirg in the medium size pots in each carbon dioxide treatment (4 replicates $x 3$ root sizes $\times 2 \mathrm{CO}_{2}$ levels $\times 3$ pot sizes $\times 2$ sampling periods $=144$ samples).

7) The distance from the root tip to where suberization and lignification occurs will be measured on a sub-sample of root tissue using staining techniques.

8) The number of periderm layers at various distances from the root tip will be measured on sub-samples of root tissue to determine where cortex cells are shed. 
Field Experiments

Root Initiation

Location: This study will be conducted in the A (- chamber ambient $\mathrm{CO}_{2}$ ), L (ambient $\left.\mathrm{CO}_{2}\right), \mathrm{M}\left(+150 \mathrm{ppm} \mathrm{CO}_{2}\right), \mathrm{H}$ (+350 ppm $\mathrm{CO}_{2}$ ) open top chambers and the $\mathrm{F}$ (- chamber $+350 \mathrm{ppm} \mathrm{CO}_{2}$ ) area at the University of California Riverside research garden.

Plant material: Cladodes were selected from the edge columns and rows in each chamber, columns $A$ and $L$ and rows 1 and 8 (Figure 1).

Sampling schedule: Cladodes will be sampled for root biomass 7 , $14,21,30,45,60,75$, and 90 days after planting (Table 1). The complete root system of each cladode will be traced out and excavated by hand ( 4 replicates $x 5$ chambers $\times 8$ periods $=160$ )

Measurements: Parameters measured on the recovered roots will be the same as those described previously for day $30 / 45$ for roots recovered from cladodes growing the medium sized pots in the walk in growth room at UCLA.

\section{PPFD Reduction and Root Pruning}

Location: The research will be carried out in the $A, L, M, H$, and $F$ areas/chambers at UCR.

Piant materizi: In eacii chamber cladodes A3, A4, A5, Ãú, ij3, I4, L5, and $L 6$ will be used for the light reduction experiment; cladodes $A 2, A 7, B 1, B 8, K 1, K 8, L 2$ and $L 7$ will be used for 
the root pruning experiment. Cladodes GI, HI, II, and JI will be the controls for both experiments.

Manipulations: Light reduction - After cladodes from locations A5, A6, L5 and L6 are harvested replacement cladodes will be planted on day 7 and shaded to reduce PPFD by 50\%. Sixty days after planting these cladodes will be harvested, on day 67 ( 4 replicates $\times 5$ chambers $=20$ samples). After cladodes from locations A3, $\$ 4, \mathrm{~L} 3$, and L4 are harvested on day 14, replacement cladodes will be planted on day 14 and shaded to reduce PPFD by $90 \%$. Sixty days after planting dise cladodes will be harvested, on day 75, (4 replicates $x 5$ chambers $=20$ samples). Cladodes $\mathrm{GI}, \mathrm{HI}, \mathrm{II}$, and JI harvested on day 60 will be the controls for the two shading treatments.

Root reduction - After cladodes from locations A7, B8, L7, and $\mathrm{k} 8$ are harvested on day 21 , replacement cladodes will be planted on day 21. For the following 60 days, root growth will be restricted to $50 \%$ of that measured at day $7,14,21$, 30,45 , and 60 . Sixty days after planting, on day 81 , these cladodes will be harvested ( 4 replicates $\times 5$ chambers $=20$ samples). After cladodes from locations A2, B1, K1, and L2 are harwested on day 30 , replacement cladodes will be planted on day 30. For the following 60 days, root growth will be restricted to 108 of that measured at day $7,14,21$, 30,45 , and 60 . Sixty tays after planting, on day 90 , these cladodes will be harvested ( 4 replicates $\times 5$ chambers $=20$ 
samples). Cladodes $G I, H I$, II JI harvested on day 60 will be the controls for the two root reduction treatments.

Measurements: Parameters measured on the recovered roots will be the same as those described previously for day $30 / 45$ for roots recovered from cladodes growing the medium sized pots in the walk in growth room at UCLA. 
Project 4 MORPHOLOGY - Kinematics of cladode expansion

Preliminary experiment in growth rooms

Objective: learn how to measure movement trajectory of areoles, stained dots, and trajectory of cell and stomatal cells from areoles and to measure cell growth velocity; practice mathematical manipulation.

Plant Material: The cladodes use in growth room experiment of Project 2 - PARTITIONING will also be used for this project. Measurements: (1) measure movement of stained dots and areoles, plot movement trajectory; (2) count cell number, measure cell length, cell growth velocity; (3) stomatal cell differentiation and flow with cladode expansion.

Experiment in the growth rooms

objective: quantitative description of both the displacement and the expansion of cladode tissue elements, including lateral meristem activity, cell density gradient, cell length, stomata flow.

Location: two existing walk in growth rooms at the Laboratory of Biomedical and Environmental Sciences, UCLA (23-172A and 23172B), will be used. One room will be maintained at ambient level of carbon dioxide and one at 350 ppm above ambient concentration.

Schedule: This experiment will begin after the growth room experiments for Projects 2 and 3 are completed. 
Plant material: Forty-eight similar sized cladodes from 1 ascension of 0 . ficus-indica from Mexico (either 1228, 1296, or 1300$)$ will be used $\left(2 \mathrm{CO}_{2}\right.$ levels $\mathrm{X}_{2}$ light levels $\mathrm{X}_{3}$ drought periods $\times 4$ replicates $=48$ plants). Cladodes will be planted in the medium size pots used in Project 2 , in a mixture of $50 \%$ soil from the University of California at Riverside research garden and 50 sandbox sand and will be watered every other day with $1 / 10$ strength Hoagland's solution for control.

Treatments: 1) Light levels will be full growth room light and 50 reduction in growth room light. 2) The three drought. periods will be normal watering, withhold watering so water potential arops below $-0.5 \mathrm{MPa}$ for 10 days, and withhold watering so water potential drops below $-0.5 \mathrm{MPa}$ for 20 days. 3) Two $\mathrm{CO}_{2}$ levels, ambient and $+350 \mathrm{ppm} \mathrm{CO}_{2}$.

Measurements and Analysis Methods: trace aerole movement to get movement trajectory, trace cell movement from areoles and then describe the trajectory with the fluid flow equation such as:

$$
\frac{D a}{D t}=\frac{\partial a}{\partial t}+v \cdot \nabla a
$$

where

a is a gicinth field variable, $t$ is time, and $v$ is growth velocity (rate of displacement from a material origin in the plant. Equation means the material rate of change (cell specific) equals 
the rate of change at the position instantaneously occupied by the tissue element, plus the rate of change due to displacement to a new position.

Measure cell length (or cell density), in the case of onedimensional growth, then

$$
\text { Rate of cell division }=\frac{1}{I}\left[\frac{\partial u}{\partial I}-\frac{u}{I} \frac{\partial l}{\partial x}\right]
$$

where 1 is cell length, $u$ is growth rate, $x$ is position. Expected results: Trajectory of areole movement, strain rates, local production rates, cell division rates, and cell elongation rates at two $\mathrm{CO}_{2}$, water, and light conditions. 
Project 5 ABSORPTANCE - Light absorption and reflection in opuntia ficus-indica exposed to elevated $\mathrm{CO}_{2}$

Objectives: To determine light absorptance and reflectance for whole cladodes and tissue sections across the chlorenchyma in o. ficus-indica. The relationship between tissue structure and its functions in light absorption and $\mathrm{CO}_{2}$ fixation will be investigated.

Location: This project will be carried out in the $A$ (amient $\mathrm{CO}_{2}$ - chamber), I (ambient $\mathrm{CO}_{2}+$ chamber), $\mathrm{M}\left(+150\right.$ ppm $\left.\mathrm{CO}_{2}\right)$, and $\mathrm{H}$ (350 ppm $\mathrm{CO}_{2}$ ) chambers/locations at the UCR research gradens.

Plant material: Planted cladodes D7, E7, F7, G7, H7 and I7 in each location will be reserved for this project. Ten replicate samples from spring 1992 cladodes will be obtained on eacn sampling day.

Schedule: Experiments will start when a sufficient number of Spring 1992 cladodes reach a width of $5 \mathrm{~cm}$, or two weeks after daughter cladode initiation. Ten replicated samples $\left(3.12 \mathrm{~cm}^{2}\right.$ ) will be obtained from cladodes of similar size in each chamber/location on days $14,30,45$ and after $2,3,5$, 7, and 10 months. Five samples will be used for light measurements and five for chlorophyll content and acidity. Measirements: 2) The thickness of the cuticla, spideimis, chlorenchyma, and water storage parenchyma will be measured using a stereo microscope and a bright field microscope. 
Publishable photos will be taken using a scanning electron microscope.

2) Reflectance will be measured using a LI-1800 integrating sphere with a LI-1820 photo sensor at $450,550,680$, and 860 $\mathrm{nm}$ and scanned from $300 \mathrm{~nm}$ to $1000 \mathrm{~nm}$.

3) Tissue absorptance and transmittance through the chlorenchyma will be determined on the rest of the tissue using the radiospectrometer by repeated removing $1.0 \mathrm{~mm}$ sections from the bottom of the tissue. After each $1.0 \mathrm{~mm}$ section is removed absorptance and transmittance will be remeasured until all mesophyll tissues are removed. Forward transmitting, forward scattering, and backward scattering light across the intact tissues will also be scanned with a fiber optic probe at $450,550,680$, and $860 \mathrm{~nm}$.

4) Transmittance and reflectance by cuticle and epidermis layers, which have been obtained by removing the mesophyll tissue with a razor blade, will be determined at 450, 550, 680 , and $860 \mathrm{~nm}$.

5) Chlorophyll contents and acidity will be measured on 1.0 $\mathrm{mm}$ thick peridermal sections of the chlorenchyma tissue.

Expected results: 1) Absorptance, transmittance, and reflectance vs carbon dioxide

2) Thickness of the cuticle, CHL, and WSP

3; Chlorophyll and chloroplast distribution across line CHL

4) Acid contents across the $\mathrm{CHL}$ vs $\mathrm{CO}_{2}$

5) Light distribution across CHL 
6) Combining the effects of $\mathrm{CO}_{2}$ and light distribution of assess the adaptive features of o.ficus-indica. 
Project 6 NUTRIENTS AND SECONDARY COMPOUNDS - Effects of Elevated Carbon Dioxide on macro- and micro-nutrient concentrations and precursors of secondary quantitative compounds in opuntia ficus-indica

objective: Determine the effect of elevated carbon dioxide on macro- and micro-nutrient concentrations and on secondary compounds in 0 . ficus-indica grown under various levels of carbon dioxide.

Location: This study will be carried out in the A (ambient $\mathrm{CO}_{2}-$ chamber) I (ambient $\mathrm{CO}_{2}$ tchamber), $\mathrm{M}$ (+150 $\mathrm{ppm} \mathrm{CO}_{2}$ ), and $\mathrm{H}$ $\left(+350 \mathrm{ppm} \mathrm{CO}_{2}\right)$ chambers/locations at the UCR research gardens.

Plant material: This project will utilize spring 1992 cladodes from planted cladodes C2, D2, E2, F2, G2, H2, I2, and J2. Measurements will be made when the daughter cladodes are about $10 \mathrm{~cm}$ in length. Cladode tissue will be separated into cuticle, chlornychema, and water storage paranychema.

Measurements: 1) nitrogen concentration (5 replicated $x 5$ treatments $=25$ samples) using micro Kjeldahl digestion. 2) macro- and micro-nutrient concentrations ( 5 replicates $x$ 5 treatments $=25$ samples) using DC arc optical emission spectometry, $50 \mathrm{mg}$ of tissue 3) caloric curitent (5 replicates, 3-4 internal replicated may be required due to variability of the small samples, $\times 5$ 
treatments $=25$ samples, but 75 - 100 meausrements) using a Gentry bomb calorimeter, 1 gram of tissue

4) mucilage content usi.ng methods described in Goldstein and Nobel 1991, 4 grams of tissue (13 $\mathrm{mm}$ cork borer)

5) isoprenoids/terpenoids/essential oils (for methods see pp 107-116 of Harborne - Gas liquid chromatography and thin layer chromatography)

7) phenolic compounds (for methods see Ragan and Jensen 1977)

8) tanin (for methods see page 84-88 of Harborne) 
Project 7 Productivity - The productivity of opuntia ficus-indica growing will elevated concentrations of carbon dioxide

Objective: To measure the productivity of 0 . ficus-indica growing under three concentration os carbon dioxide.

Location: This project will be carried out in the $A$ (- chamber ambient $\left.\mathrm{CO}_{2}\right), \mathrm{L}$ (ambient $\left.\mathrm{CO}_{2}\right), \mathrm{M}\left(+150 \mathrm{ppm} \mathrm{CO}_{2}\right), \mathrm{H}$ (+350 ppm $\mathrm{CO}_{2}$ ), and $\mathrm{F}$ (- chamber $+350 \mathrm{ppm} \mathrm{CO}_{2}$ ) at the University of California Riverside experimental garden.

Plant material: The 24 planted cladodes in the center $\mathrm{m}^{2}$ in each chamber/area will be reserved for productivity measurements, i.e., rows $3,4,5$, and 6 of columns D, E, F, G, H, and I.

Measurements: 1) The length of each daughter cladode growing on the 24 planted cladodes in the center $\mathrm{m}^{2}$ of each chamber/area will be measured monthly (24 cladodes $\times 5$ locations $=120$ )

2) After stem area index (SAI) reaches 4, cladodes will be harvested monthly or every two months as needed to maintain a SAI of 4 .

3) Harvested material will be dried and weighted.

4) The center $\mathrm{m}^{2}$ of planted cladodes will be harvested after two years exposure to elevated carbon dioxide. 
References on elevited carbon dioxide and CAM plants

Black, C. C., Jr. 1986. Effects of $\mathrm{CO}_{2}$ concentrations on photosynthesis and respiration of $\mathrm{C}_{4}$ and CAM plants. In $\mathrm{H}$. Z. Enoch and B. A. Kimball (eds.). Carbon dioxide enrichment of greenhouse crops, Vol. 2: Physiology, Yield, and Economics, CRC Press, Boca Raton, FI pp. 29-40.

Garcia de Cortazar, V. and P. S. Nobel. 1990. Worldwide environmental productivity indices and yield predictions for a CAM plant, opuntia ficus-indica, including effects of doubled $\mathrm{CO}_{2}$ levels. Agri. For. Meteor. 49:261-279.

Holtum, J. A. M, M. H. O'Leary and C. B. Osmond. 1983. Effect of varying $\mathrm{CU}_{2}$ partial pressure on photosynthesis and on carbon isotope composition of carbon-4 of malate from the Crassulacean acid metabolism plant Kalanchoe daigremontiana Hamet et Perr. Plant Physiol. 71:602-609.

Huerta, A. U. and I. P. Ting. 1988. Effects of various levels of $\mathrm{CO}_{2}$ on the induction of Crassulacean acid metabolism in Portulacaria afra (L.) Jacq. Plant Physiol. 71: 602-609.

Idso, S. B., B. A. Kimball, M. G. Anderson, and S. R. Szarek. 1986. Growth response of a succulent plant, Agave

vilmoriniana, to elevated $\mathrm{CO}_{2}$. Plant Physiol. 80: 796-797.

Nobel, P. S. 1991. Environmental productivity indices and prcductivity for opuntia ficus-indicia under current and elevated atmospheric $\mathrm{CO}_{2}$ levels. Plant, Cell Envir. $14: 637-646$.

Nobel, P. S. and V. Garcia de Cortazar. 1991. Growth and predicted productivity of opuntia ficus-indica for current and elevated carbon dioxide. Agron. J. 83: 224-230.

Nobel, P. S. and T. L. Hartsock. 1986. Short-term and long-term responses of crassulacean acid metabolism plants to elevated $\mathrm{CO}_{2}$. Plant Physiol. 82:604-606.

Nobel, P. S. and J. R. Palta. 1989. Soil $\mathrm{O}_{2}$ and $\mathrm{CO}_{2}$ effects on root respiration of cacti. Plant and Soil 120:263-271.

Szarek, S. R., P. A. Holthe, and I. P. Ting. 1987. Minor physiological response to elevated $\mathrm{CO}_{2}$ by the CAM plant Agave vilmoriniana. Plant Physiol. 83:938-940. 
Measuremnts at UCR

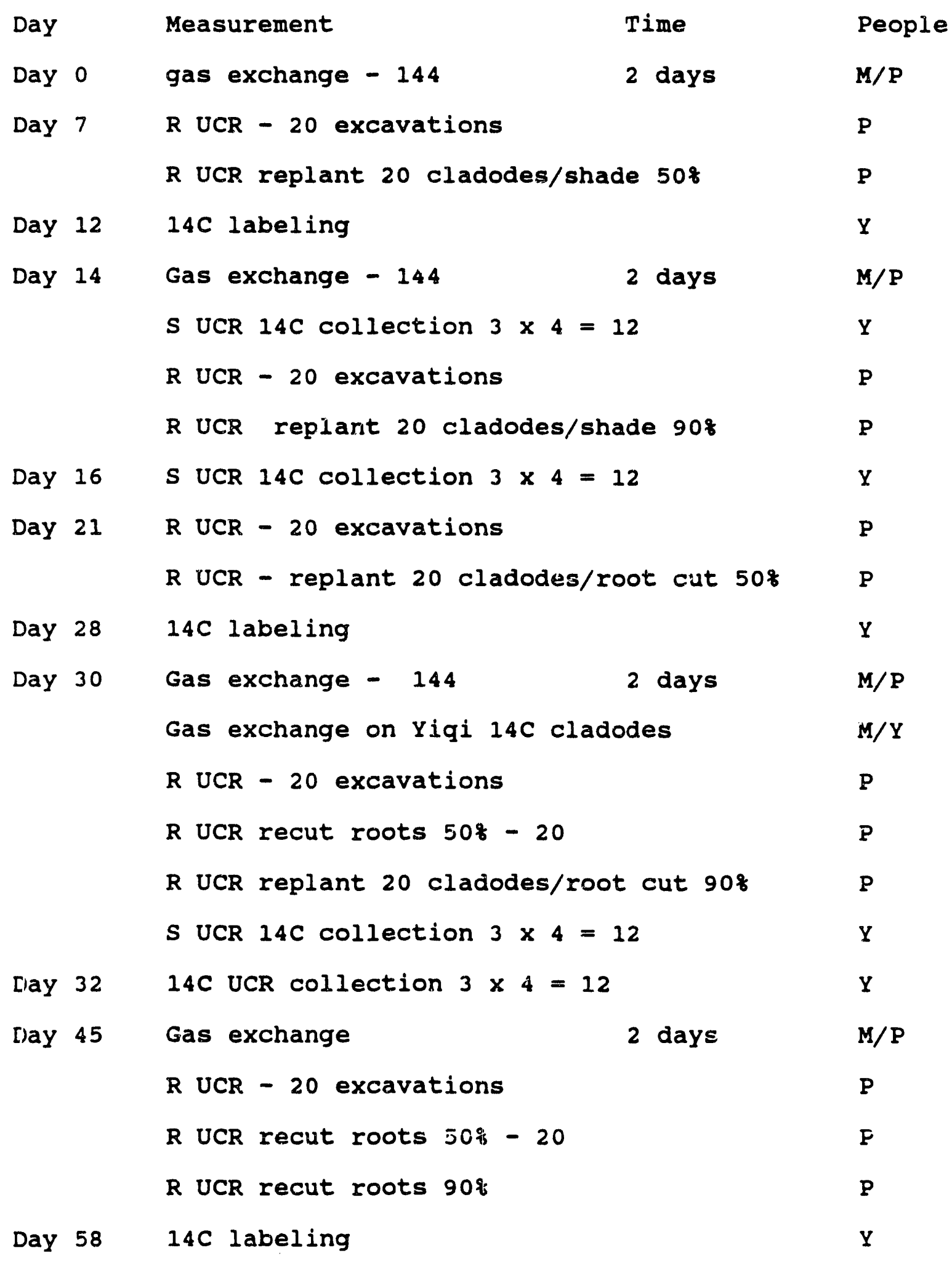




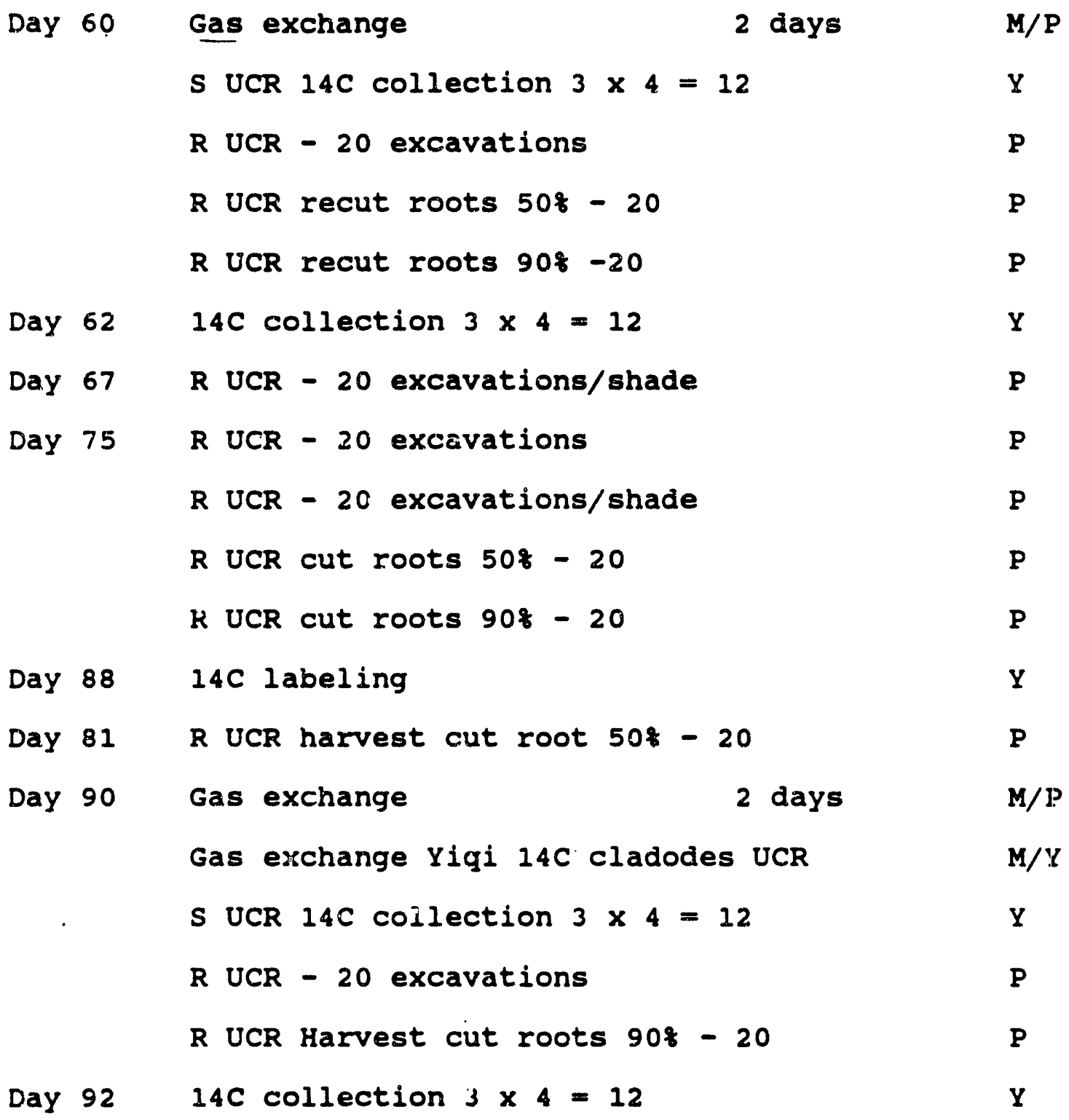


Measuremnts at UCLA

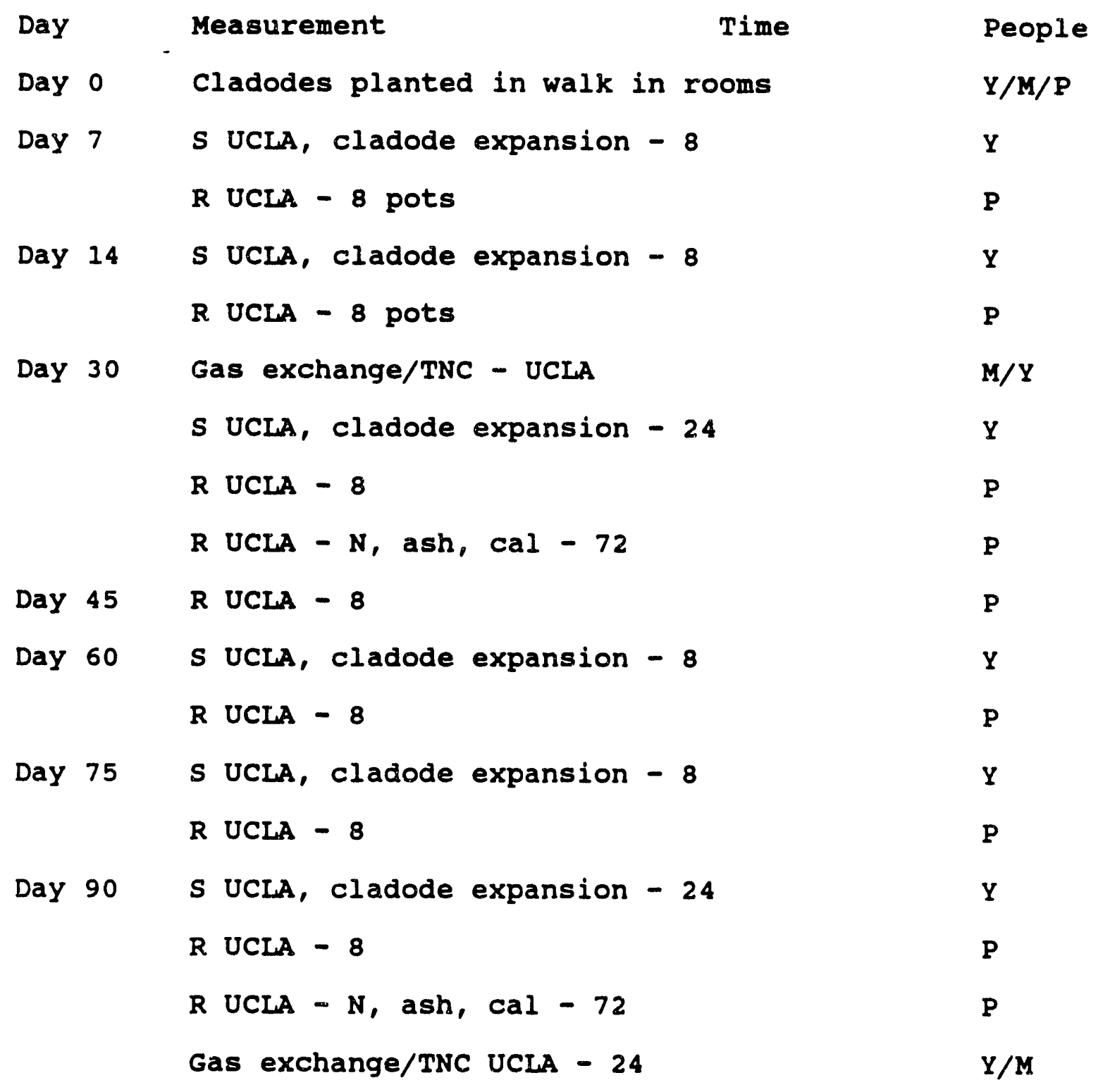




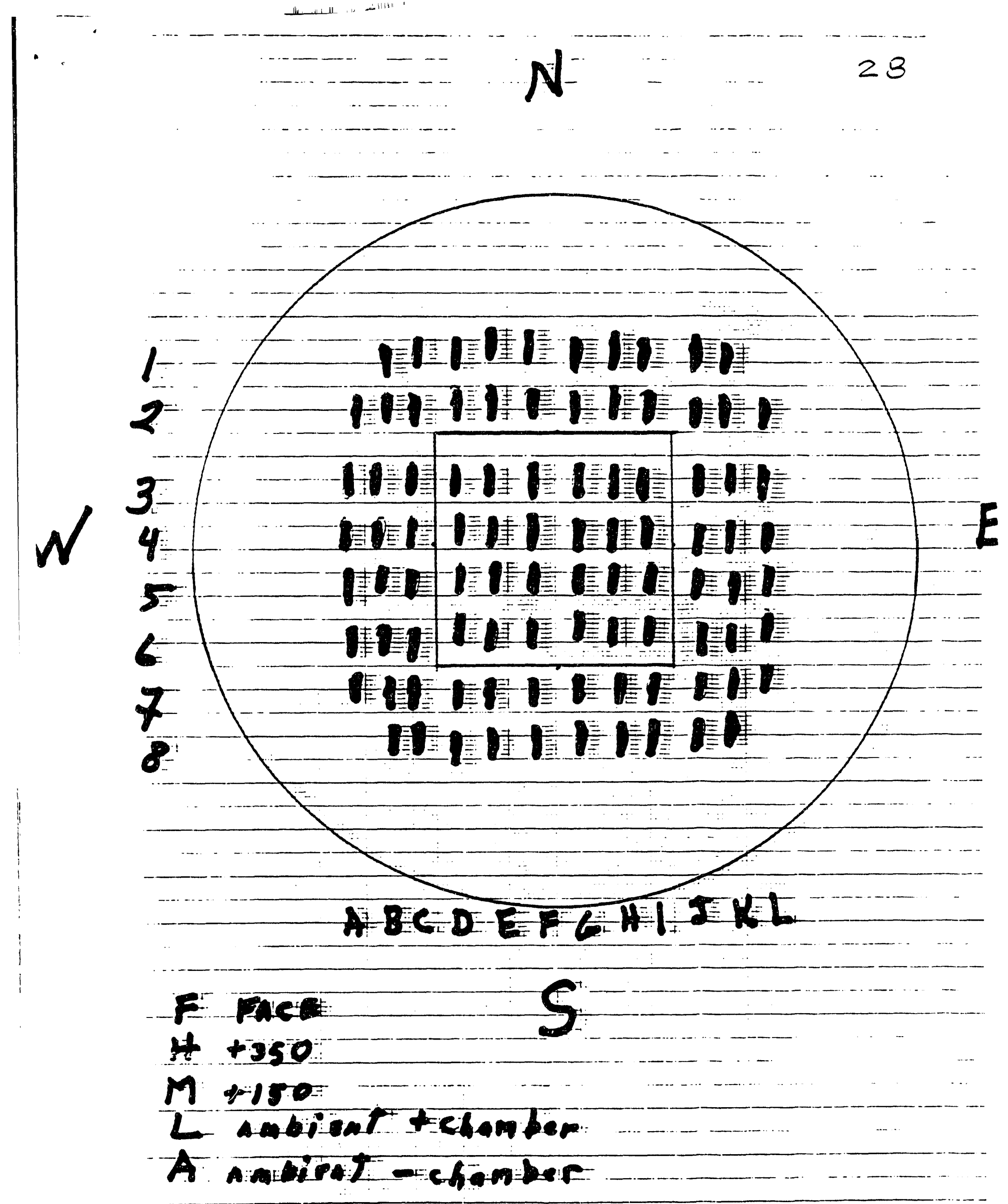




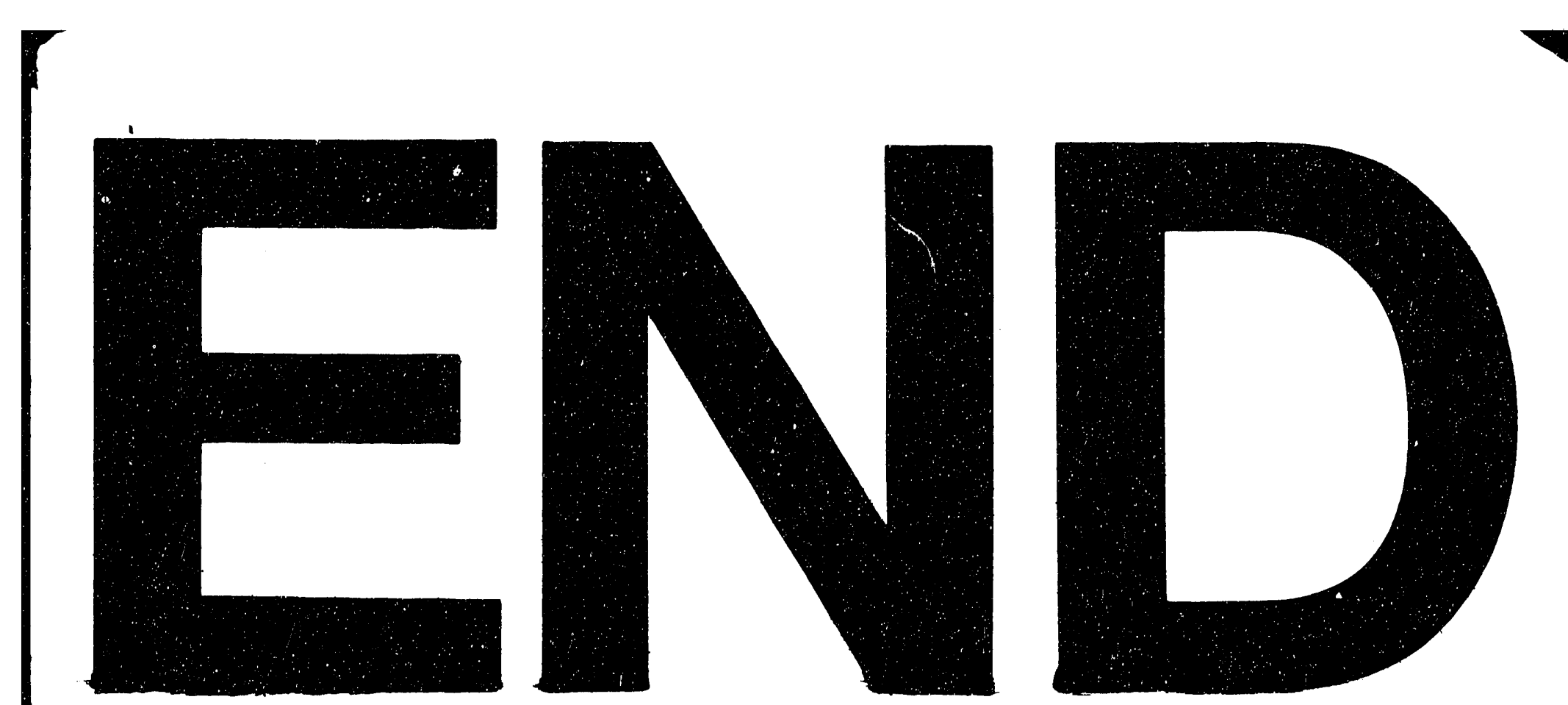




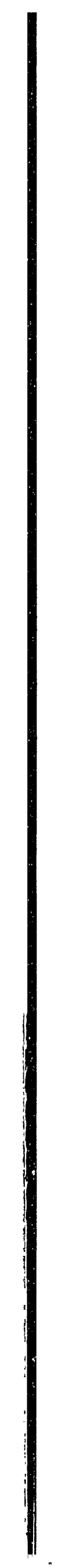

